\title{
Analysis of the cause, classification, treatment, outcome and associated injuries of pediatric pelvic ring fractures
}

\author{
Yavuz Saglam, M.D., ${ }^{1}$ Goksel Dikmen, M.D., ${ }^{1}$ Suleyman Bademler, M.D., ${ }^{2}$ \\ Murat Aksoy, M.D., ${ }^{2}$ Fatih Dikici, M.D. ${ }^{1}$ \\ ${ }^{1}$ Department of Orthopedics and Traumatology, Istanbul University Istanbul Faculty of Medicine, Istanbul \\ ${ }^{2}$ Department of General Surgery, Istanbul University Istanbul Faculty of Medicine, Istanbul
}

\begin{abstract}
BACKGROUND: Although pediatric pelvis fractures are relatively uncommon, long-term consequences and associated life-treating injuries often have a substantial impact for the rest of a child's life. The prognosis of pediatric pelvic fractures is better than that of the adults because of their greater elasticity, healing capacity and re-modelling. Fractures through the physis may lead to growth disturbance and/or acetabular dysplasia. Non-union is rare and mal-union is usually well-tolerated. The purpose of this study was to evaluate the results of a single trauma center and review the literature approach to pediatric pelvic fractures.
\end{abstract}

METHODS: Medical records were analyzed for diagnosis, the mechanism of injury, additional injuries, treatment methods, and complications. The types of fractures were classified according to Torode and Zieg classification. Patients were called back and seen at the clinic as a last follow up visit.

RESULTS: Twenty eight skeletally immature patients, under the age of I2, were treated for pelvic fracture from I997 to 2012 . Mean age was $6.8 \pm 2.4$ years. Three children with an unstable pelvic ring injury required pelvic external fixation. One patient died due to pelvic hemorrhage postoperatively. Mean follow up was $5.3 \pm 3.6$ years.

CONCLUSION: Pediatric pelvic fractures are rare but life-threating injuries. Overall good or excellent long-term results can be expected in most cases with appropriate timing and treatment.

Keywords: Elasticity; functional independence measurement score (FIM score); injury severity score (ISS); pediatric pelvis fractures; remodeling; poly-trauma; Torode and Zieg classification.

\section{INTRODUCTION}

Pediatric pelvic injuries are usually associated with high energy trauma. High energy trauma tends to occur with concomitant brain, genitourinary, intra-abdominal and thoracic injuries. ${ }^{[1,2]}$ The most common cause of pediatric pelvis fractures is being struck by a motor vehicle. Motor vehicle-pedestrian type injuries usually cause lateral compression type of pelvic fracture. ${ }^{[3-6]}$ Overall incidence has been reported between $2 \%$ to $7.5 \%$ of trauma admissions for children in trauma centers.

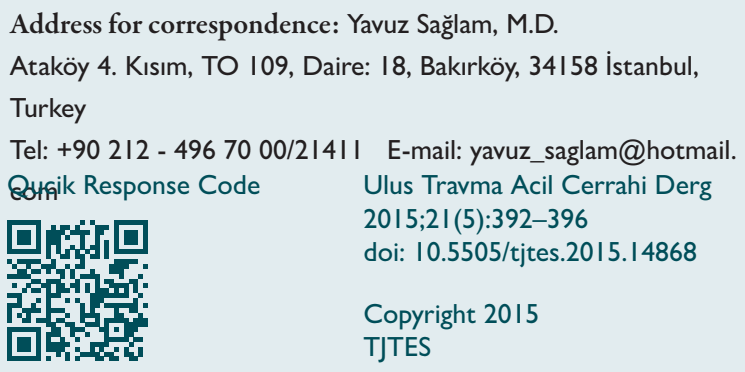

[2,3,7,8] Hospitalization periods are long and mortality is higher than other pediatric fractures. Although pediatric pelvis fractures are relatively uncommon, long-term consequences and associated life-treating injuries often have a substantial impact for the rest of their lives. ${ }^{[2,9]}$

The variety of clinical presentations in these patients makes it difficult to formulate treatment algorithms suitable for each case. The treatment of any individual patient should be tailored according to many variables, such as patients' age, fracture patterns, hemodynamic instability and associated injuries. Unstable fractures have an increased risk for genitourinary problems and a marked correlation with major hemorrhaging. ${ }^{[8]}$ Most stable fractures can be treated conservatively with protected weight bearing.

Prognosis of pediatric pelvic fractures is better than adults. [1] Children have more elasticity, greater capacity to heal and remodel. Although immaturity of the pelvis gives children an increased elasticity and re-modelation, displaced fractures $(>2 \mathrm{~cm})$ may cause leg length inequality and hip or sacroiliac 
arthritis, if articular surface is involved. ${ }^{[10,11]}$ The purpose of this study was to review the results of a single trauma center and review the literature approach to the pediatric pelvic fractures.

\section{MATERIALS AND METHODS}

The institutional review board approved the chart review for this study, and informed consent was obtained from all patients. From January 1997 to November 2012, twenty-eight children with pelvic fracture were treated at our institution. We retrospectively reviewed the medical records of all patients. Patients with open triradiate cartilage at the time of trauma were included into the study. Exclusion criteria were open fracture, inadequate radiographs, incomplete data, or loss to follow-up.

Data included gender, age, mechanism of injury, fracture treatment, associated injuries (both orthopedic and non-orthopedic), functional outcome, and death rate. Mechanism of injury was classified as motor vehicle versus pedestrian, motor vehicle versus motor vehicle, falls, and other. Associated orthopedic injuries included all bony fractures excluding skull, and facial fractures. Associated non-orthopedic injuries included major chest trauma, head trauma, abdominal/visceral injuries, and urogenital trauma. Injury severity score (ISS) of all patients were evaluated retrospectively. ${ }^{[2]}$ All radiographs, including computed tomography scans when available, were reviewed to classify each pelvic fracture according to the system proposed by Torode and Zeig[5] (Fig. I).

Patients were called back and seen at the clinic as a follow up visit at one year after injury. Outcome criteria of functional independence measurement classification for transfer mobil-

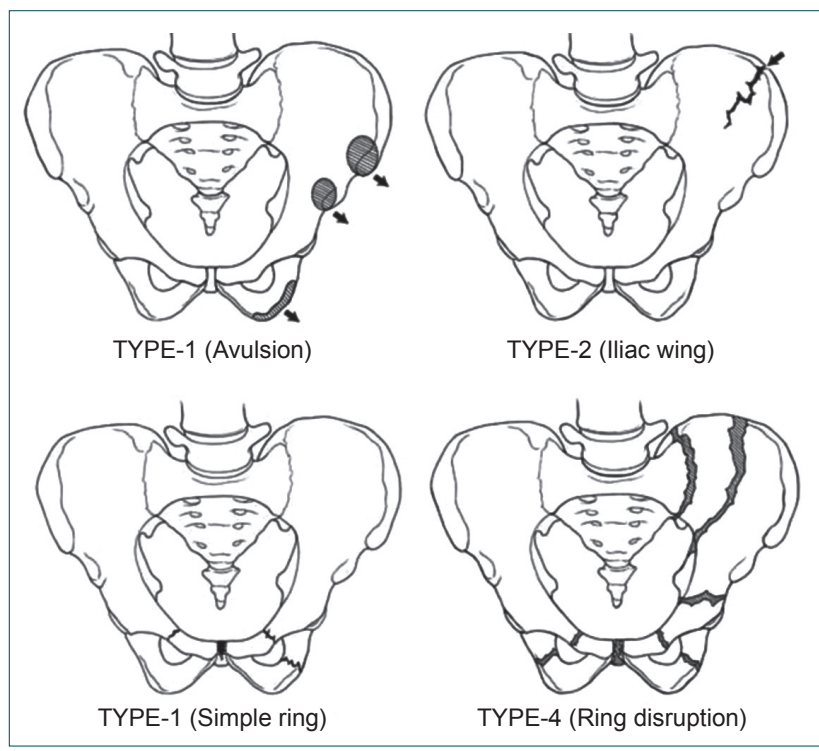

Figure 1. Torode and Zieg Classification of pediatric pelvis fractures. ${ }^{[5]}$
Table I. Functional independence scale

\begin{tabular}{ll}
\hline Group I & Complete dependence \\
Group 2 & Modified dependence \\
Group 3 & Independence with device \\
Group 4 & Complete independent \\
\hline
\end{tabular}

Table 2. Additional injuries

\begin{tabular}{lc}
\hline Additional injuries & $\begin{array}{c}\text { Number of } \\
\text { patients }\end{array}$ \\
\hline Head injury & 9 \\
Long bone fractures (femur, tibia, forearm) & 9 \\
Pulmonary contusion & 6 \\
Intra-abdominal solid organ injury & 5 \\
Genitourinary injury & 5 \\
Multiple rib fracture & 4 \\
Perineal laceration & 3 \\
Pneumothorax & 3 \\
Intra-muscular hematomas & 2 \\
Maxilla-facial fracture & 1 \\
\hline
\end{tabular}

ity and locomotion was assessed. ${ }^{[13]}$ Details of functional independence scale are shown in Table I.

\section{RESULTS}

Here were seventeen male and eleven female patients with a mean age of $6.8 \pm 2.4$ years (range, 3 to 12 years). The most common mechanism of injury was a pedestrian being hit by a motor vehicle with twenty-two (78\%) patients, which was followed by fall from a height with four (14\%) and motor vehicle accidents with two (8\%) cases.

Majority of the patients ( 15 out of 28) were diagnosed with Torode and Zieg type 2 fractures, which is an iliac ring fracture. Four children were diagnosed with type I avulsion frac-

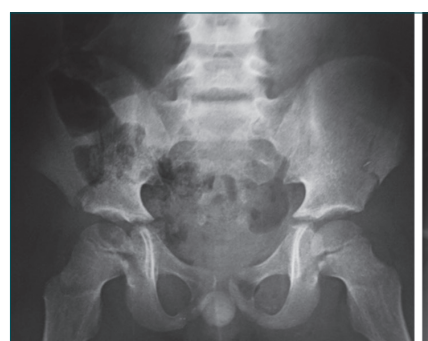

Torode - Zieg Type 2 Fracture (bilateral iliac wings)

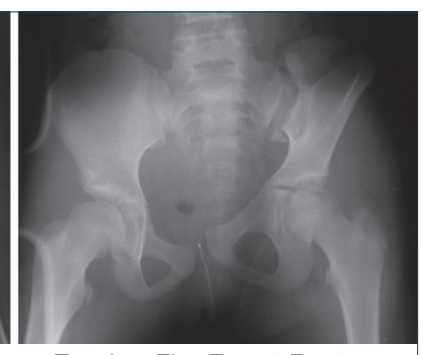

Torode - Zieg Type 4 Fracture (ring disruption)
Figure 2. Initial AP pelvic X-rays. 
ture, six children had type 3 simple ring fracture and three children sustained type 4 ring disruption (Fig. 2).

Computed tomography (CT) was undertaken in twenty-one patients to evaluate sacroiliac joints and sacrum to aid decision making in planning treatment. CT was also helpful for pediatric surgeons to evaluate intra-pelvic vital structures such as bladder, kidney, spleen, liver, and etc (Fig. 3).

Additional injuries were very common. Head injuries and additional long bone (forearm, femur and tibia) were reported in nine cases, which are the most common concomitant injury. Six pulmonary contusions, five intra-abdominal solid organ (liver, kidney, spleen) hematomas, five genitourinary injuries, four multiple rib fractures, three perineal lacerations, three pneumothoracis, two intramuscular hematomas, and one maxilla-facial fracture were reported in the medical records (Table 2). Mean ISS score at initial emergency application was $21.1 \pm 10.3$ (range, 2-57).

Five children required an orthopedic surgical intervention. Three children with an unstable pelvic ring injury required pelvic external fixation. Other orthopedic surgeries were close reduction external fixation (CREF) of 2 femur shaft fractures, closed reduction internal fixation (CRIF) of a forearm fracture and open reduction internal fixation (ORIF) of a displaced femoral neck fracture. There was only one patient requiring pelvic and femoral external fixation at the same time.

A total number of six non-orthopedic surgeries were performed and all of these patients had instable pelvic ring injuries. These non-orthopedic procedures consisted of a mix of pediatric surgical $(n=2)$, neurosurgical $(n=2)$, plastic surgical $(n=I)$, and urosurgical $(n=I)$ cases. Torode type I, 2 and 3 fractures were treated non-operatively with pain control and weight bearing as tolerated for 4 to 6 weeks. Children could resume normal activity level within 8 weeks (Fig. 4).
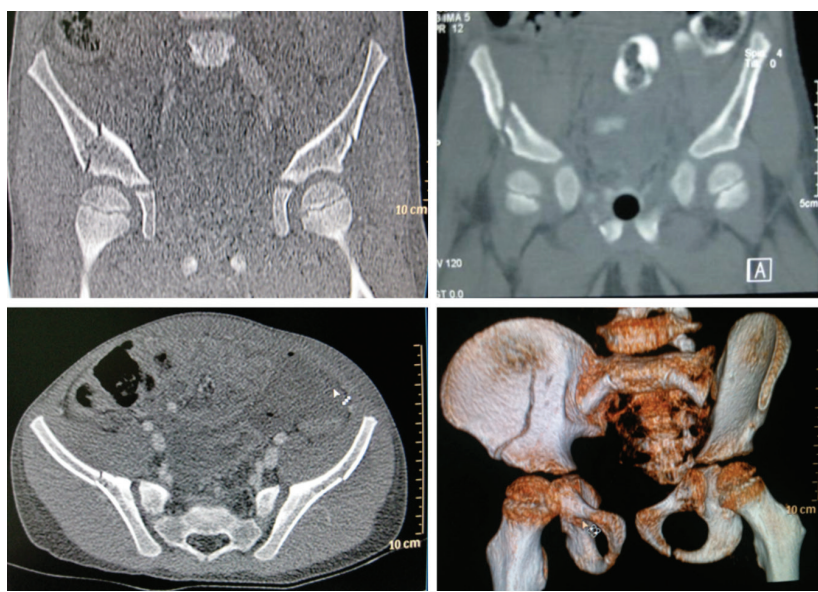

Figure 3. CT scan accelerates and facilitates the diagnose.
Mean follow-up was 5.3 \pm 3.6 years (range, I.4-9.8 years). One patient with an unstable pelvic fracture, femur fracture, brain contusion, pneumothoracis, splenic and liver hematoma died in the intensive care unit on the first postoperative day. Although there was no evidence of physeal injury of proximal tibia, one patient developed a significant genu varum deformity. All patients who survived returned to their daily life activities completely independent one year after injury.
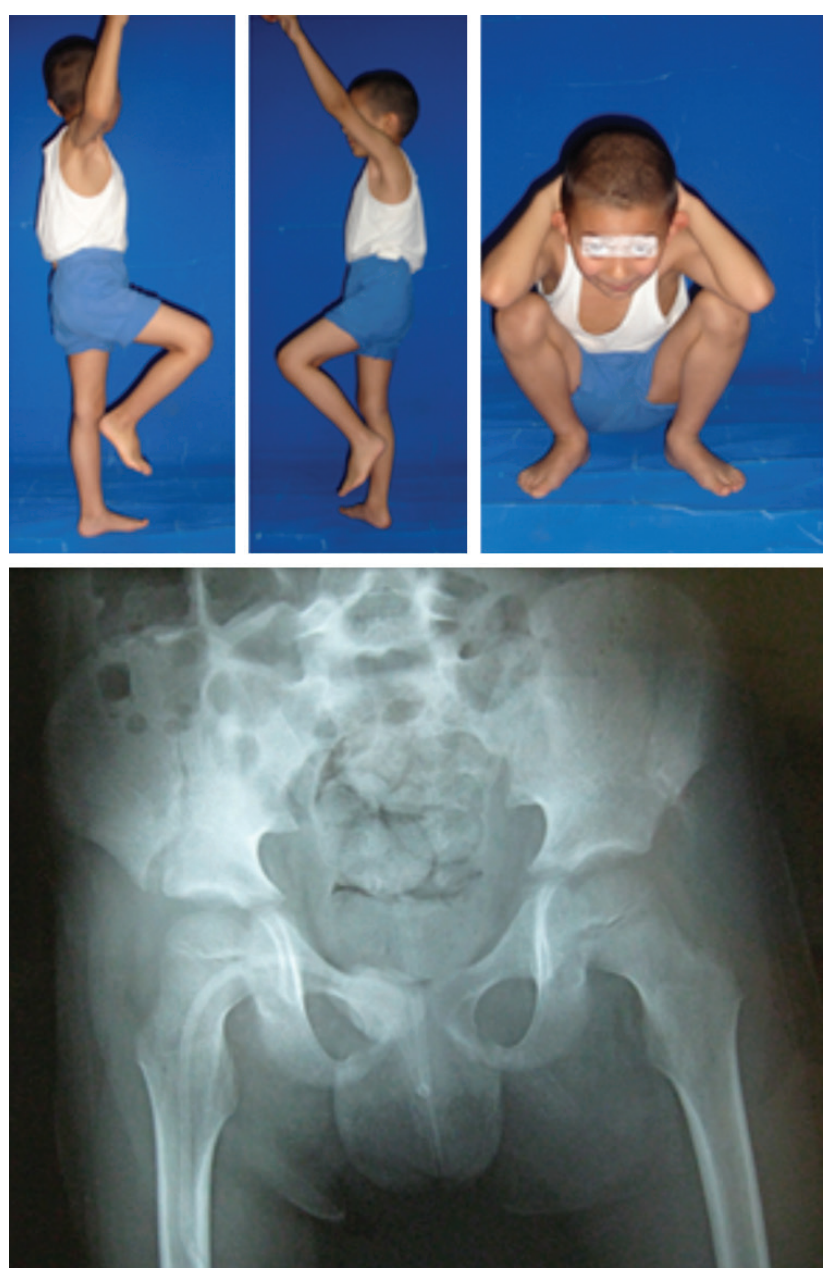

Figure 4. Clinical and radiographic status after 6 weeks of symptomatic treatment.

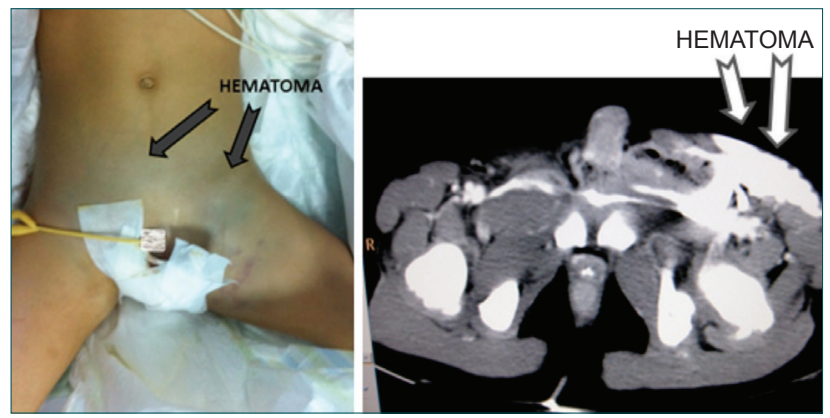

Figure 5. Excessive hematoma of the pelvic fracture, which leads to be a predictor of Moral-Lavellee lesion. 


\section{DISCUSSION}

Evaluation of a poly-traumatized child begins with assessment of airway (A), breathing (B) and circulation (C). Injuries of the pelvis should be carefully evaluated. Visual inspection of the pelvis and perineum, lacerations and ecchymosis around the pelvis, scrotal, vaginal and urethral injury should be evaluated. A rectal examination is necessary to identify rectal tears. Unstable pelvic ring fractures have an increased rate of genitourinary injury. ${ }^{[14]}$ If there is suspicion about urethral injury, a retrograde urethrogram should be performed before catheterization. Morel-Lavellee lesion (shearing of the skin and subcutaneous tissue) (Fig. 5), gentle palpation of the pelvic bony structures, hip range of motion, neurologic examination, crepitation , and excessive mobility should be noted and documented as potential sources of life-threatening pelvis fracture.

Consistent with our findings, Upperman et al. have reported that nearly $75 \%$ of pelvic ring fractures are caused by motor vehicle related injuries. ${ }^{[13]}$ In our series, pedestrians versus motor vehicle crashes were nearly 10 times more common than motor vehicle crashes alone (22 vs. 2 ). This may result with a lateral compression injury, which decreases the pelvic volume and does not resolve with significant bleeding. ${ }^{[1,10,15]}$ Fall from height was second most common type of etiology with four patients (14\%). In a series of one hundred and sixtysix patients, Silber et al. have reported only one $(0.6 \%)$ open book injury in children. ${ }^{[16]}$ Pelvic ring disruptions can occur by vertical shearing which can be caused by a fall. If vertical displacement is more than $2 \mathrm{~cm}$, most authors advocate reduction and stabilization to avoid leg length inequality. ${ }^{[9,17]}$

Additional injuries, such as head, thorax, intra-abdominal visceral organs, intra-pelvic neurovascular injuries are common in pediatric pelvic fractures. ${ }^{[4,18]}$ Abdominal trauma is reported between $11 \%$ and $21 \%$ in pediatric pelvis fractures. ${ }^{[1,19]}$ In this series, thirteen (46\%) of the children had additional injuries, and the most common additional injuries were head injury and long bone fractures.

Standard AP plain radiograph of the pelvis and thorax should be obtained for assessment. Although some authors argue that CT does not change treatment methodology, ${ }^{[18]}$ it is considered to be the most effective method of evaluating pelvis fractures. ${ }^{[15,20,21]}$ Volumetric reconstruction helps the surgeon to evaluate fracture pattern and make a preoperative plan. [20] In a poly-traumatized child, concomitant head, thorax and abdominal injuries can be diagnosed by a quick series of CT.

Skeletally immature children have different fracture patterns. [16] With an open triradiate cartilage (TRC), Torode and Zieg type 2 (iliac wing) or type 3 (simple ring) fractures are the most common patterns. Bony structures of the pelvis are weaker than pelvic ligaments. Most of these fractures heal rapidly without any complications. ${ }^{[22]}$ Spica cast immobilization may be needed for noncompliant children. Casting a child with multiple organ injuries may also cause difficulty for pediatric surgeons and urosurgeons.

As the child gets older and TRC closes, elasticity of the pelvis decreases in adolescents. They usually sustain fractures of the acetabulum or diastasis of symphysis pubis and sacroiliac joints. ${ }^{[15]}$ In addition, type I (avulsion) injuries are common in adolescents. These are usually low energy fractures and related to sports. ${ }^{[7]}$ Most avulsion fractures do not need surgical intervention except for the case of professional degree sports players.

Compared to adults, children have low mortality rates in pelvic injuries. ${ }^{[3,4,11]}$ Overall mortality rate of $3.5 \%$ was consistent with other publications in the literature. ${ }^{[1,13]}$ In a report by Vitale and colleagues, head injury and high injury severity (ISS) scores have good correlation with the overall mortality in pediatric pelvis fractures. ${ }^{[23]}$ Children's greater elasticity protects pelvic ring against displaced fractures. ${ }^{[10,17]}$ Elasticity of vessels in children requires more energy to cause major hemorrhage versus atherosclerotic and friable vessels in adults. ${ }^{[1,3,4]}$ Moreover, vessels in children can easily undergo vasoconstriction and control bleeding. ${ }^{[1,3]}$

Non-union is rare and malunion is usually well tolerated in children. ${ }^{[1]}$ Most late complications are related to sacroiliac disruptions and acetabular fractures. ${ }^{[17]}$ Fortunately, acetabular fractures and sacroiliac injuries are not common in children who have open TRC. Fractures through the TRC may lead to growth disturbance of the acetabulum and cause acetabular dysplasia. ${ }^{[9,17,24]}$ Neurologic complications, such as sciatic nerve injury, lumbar or sacral plexus injuries are seldom and usually resolves within two months of the trauma. ${ }^{[17]}$

There is not sufficient data in the literature about functional outcomes of pelvic fractures in children. The functional independence measurement score is used in many rehabilitation settings to assess efficacy of treatment. In this study, we reviewed retrospectively the records of children who sustained pelvic fractures at our institution and reported their functional independence at one year after injury. Our data show that a substantial number of patients are dependent for transfer at discharge, but regardless of the severity of the pelvic fracture, all patients were completely independent for mobilization.

This study has some limitations, most of which are inherent to its retrospective design. Assessment of clinical outcomes was limited to chart documentation and call back visits. Most of the children were still in childhood and follow-up was not enough to become skeletally maturity.

In conclusion, pediatric pelvic fractures are rare but life-threating injuries. Fractures of the pelvic ring should be assessed carefully by X-ray and CT imaging. Management of patients with pelvic fractures often requires a multidisciplinary approach. Overall good and excellent functional results can be expected in most cases with appropriate timing of treatment. 
Conflict of interest: None declared.

\section{REFERENCES}

1. Ismail N, Bellemare JF, Mollitt DL, DiScala C, Koeppel B, Tepas JJ 3rd. Death from pelvic fracture: children are different. J Pediatr Surg 1996;31:82-5. CrossRef

2. Peltier Lf. Complications Associated With Fractures Of The Pelvis. J Bone Joint Surg Am 1965;47:1060-9.

3. Grisoni N, Connor S, Marsh E, Thompson GH, Cooperman DR, Blakemore LC. Pelvic fractures in a pediatric level I trauma center. J Orthop Trauma 2002;16:458-63. CrossRef

4. Silber JS, Flynn JM, Koffler KM, Dormans JP, Drummond DS. Analysis of the cause, classification, and associated injuries of 166 consecutive pediatric pelvic fractures. J Pediatr Orthop 2001;21:446-50. CrossRef

5. Torode I, Zieg D. Pelvic fractures in children. J Pediatr Orthop 1985;5:76-84. CrossRef

6. Vazquez WD, Garcia VF. Pediatric pelvic fractures combined with an additional skeletal injury is an indicator of significant injury. Surg Gynecol Obstet 1993;177:468-72.

7. Demetriades D, Karaiskakis M, Velmahos GC, Alo K, Murray J, Chan L. Pelvic fractures in pediatric and adult trauma patients: are they different injuries? J Trauma 2003;54:1146-51. CrossRef

8. McIntyre RC Jr, Bensard DD, Moore EE, Chambers J, Moore FA. Pelvic fracture geometry predicts risk of life-threatening hemorrhage in children. J Trauma 1993;35:423-9. CrossRef

9. Tolo VT. Orthopaedic treatment of fractures of the long bones and pelvis in children who have multiple injuries. Instr Course Lect 2000;49:41523.

10. Garvin KL, McCarthy RE, Barnes CL, Dodge BM. Pediatric pelvic ring fractures. J Pediatr Orthop 1990;10:577-82. CrossRef

11. Rieger H, Brug E. Fractures of the pelvis in children. Clin Orthop Relat Res 1997;336:226-39. CrossRef
12. Baker SP, O'Neill B, Haddon W Jr, Long WB. The injury severity score: a method for describing patients with multiple injuries and evaluating emergency care. J Trauma 1974;14:187-96. CrossRef

13. Upperman JS, Gardner M, Gaines B, Schall L, Ford HR. Early functional outcome in children with pelvic fractures. J Pediatr Surg 2000;35:1002-5.

14. Batislam E, Ateș Y, Germiyanoğlu C, Karabulut A, Gülerkaya B, Erol D. Role of Tile classification in predicting urethral injuries in pediatric pelvic fractures. J Trauma 1997;42:285-7. CrossRef

15. Holden CP, Holman J, Herman MJ. Pediatric pelvic fractures. J Am Acad Orthop Surg 2007;15:172-7.

16. Silber JS, Flynn JM. Changing patterns of pediatric pelvic fractures with skeletal maturation: implications for classification and management. J Pediatr Orthop 2002;22:22-6. CrossRef

17. Heeg M, de Ridder VA, Tornetta P 3rd, de Lange S, Klasen HJ. Acetabular fractures in children and adolescents. Clin Orthop Relat Res 2000;376:80-6. CrossRef

18. Silber JS, Flynn JM, Katz MA, Ganley TJ, Koffler KM, Drummond DS. Role of computed tomography in the classification and management of pediatric pelvic fractures. J Pediatr Orthop 2001;21:148-51. CrossRef

19. Bond SJ, Gotschall CS, Eichelberger MR. Predictors of abdominal injury in children with pelvic fracture. J Trauma 1991;31:1169-73. CrossRef

20. Magid D, Fishman EK, Ney DR, Kuhlman JE, Frantz KM, Sponseller PD. Acetabular and pelvic fractures in the pediatric patient: value of twoand three-dimensional imaging.J Pediatr Orthop 1992;12:621-5. CrossRef

21. Stiletto RJ, Baacke M, Gotzen L. Comminuted pelvic ring disruption in toddlers: management of a rare injury. J Trauma 2000;48:161-4. CrossRef

22. Blasier RD, McAtee J, White R, Mitchell DT. Disruption of the pelvic ring in pediatric patients. Clin Orthop Relat Res 2000;376:87-95. CrossRef

23. Vitale MG, Kessler MW, Choe JC, Hwang MW, Tolo VT, Skaggs DL. Pelvic fractures in children: an exploration of practice patterns and patient outcomes. J Pediatr Orthop 2005;25:581-7. CrossRef

24. Bucholz RW, Ezaki M, Ogden JA. Injury to the acetabular triradiate physeal cartilage. J Bone Joint Surg Am 1982;64:600-9. CrossRef

\section{ORIJIINAL ÇALIŞMA - ÖZET}

\section{Çocukluk çağı pelvis kırıklarının etiyoloji, sınıflandırma, tedavi, sonuç ve eşlik eden yaralanmalar açısından analizi}

\section{Dr. Yavuz Sağlam, ${ }^{1}$ Dr. Göksel Dikmen, ${ }^{1}$ Dr. Süleyman Bademler, ${ }^{2}$ Dr. Murat Aksoy, ${ }^{2}$ Dr. Fatih Dikici ${ }^{1}$}

${ }^{1}$ İstanbul Üniversitesi İstanbul Tıp Fakültesi, Ortopedi ve Travmatoloji Anabilim Dalı, İstanbul

2'̇stanbul Üniversitesi İstanbul Tıp Fakültesi, Genel Cerrahi Anabilim Dalı, İstanbul

AMAÇ: Pelvis kırıkları çocukluk çă̆ında nadir görülen, hayati tehlike arz eden ve aynı zamanda sekel bırakma ihtimali yüksek olan yaralanmalardır. Doku elastisitesi, kaynama kapasitesi ve remodelasyon yetenekleri erişkinlere göre daha yüksek olduğundan pelvis kırıklarının prognozu çocuklarda erişkinlere göre daha iyidir. Kaynamama nadir görülürken, kötü kaynama ise genellikle çocuklar tarafından iyi tolere edilir. Bu çalı̧mada, tek bir travma merkezinde tedavileri sürdürülmüş hastaları geriye dönük olarak inceledik ve literatür bilgileri ışığında tartıştık.

GEREÇ VE YÖNTEM: Hasta dosyaları tanı, yaralanma mekanizması, ek yaralanmalar, uygulanan tedavi metotları ve komplikasyonlar açısında incelendi. Kırıklar Torode ve Zieg'in tarif ettiği sınıflandırmaya göre sınıflandırıldı. Hastalar kayıtlı telefonlarından son bir inceleme için geri çağııldı. BULGULAR: 1997 ve 2012 yılları arasında, ortalama yaşları 6.8 2 2.4 olan, 28 hastanın acil kliniğimize başvurduğu tespit edildi. Başvuru anında tüm hastalar 12 yaş altında idi. Üç hasta instabil pelvis kırı̆̆ı (tip 4) tanısı ile acil şartlarda ameliyat edildi. Bir hasta ameliyat sonrası erken dönemde pelvis içi aşırı kanamaya bağı kaybedildi. Ortalama 5.3 \pm 3.6 yıl takip neticesinde 27 hastanın ciddi bir sekel kalmadan normal hayatlarına devam ettikleri görüldü.

TARTIŞMA: Pediatrik pelvis kırıkları nadir görülen ancak ciddi morbidite ve mortalite riski olan yaralanmalardır. Doğru zamanlama ve uygun tedavi ile uzun dönemde iyi klinik sonuçlar gözlenmektedir.

Anahtar sözcükler: Çocuk pelvis kırığ; elastisite; fonksiyonel bağımsızlık ölçüm skoru; politravma; remodelasyon; Torode ve Zieg sınıflaması; yaralanma ciddiyet skoru.

Ulus Travma Acil Cerrahi Derg 2015;21(5):392-396 doi: 10.5505/tjtes.2015.14868 